\title{
Noninvasive Measurements of the Membrane Potential and GABAergic Action in Hippocampal Interneurons
}

\author{
Jos A. H. Verheugen, Desdemona Fricker, and Richard Miles \\ Laboratoire de Neurobiologie Cellulaire et Moleculaire, Institut National de la Santé et de la Recherche Médicale U261, \\ Institut Pasteur, 75724 Paris, France
}

\begin{abstract}
Neurotransmitters affect the membrane potential $\left(V_{\mathrm{m}}\right)$ of target cells by modulating the activity of receptor-linked ion channels. The direction and amplitude of the resulting transmembrane current depend on the resting level of $V_{\mathrm{m}}$ and the gradient across the membrane of permeant ion species. $V_{m}$, in addition, governs the activation state of voltage-gated channels. Knowledge of the exact level of $V_{\mathrm{m}}$ is therefore crucial to evaluate the nature of the neurotransmitter effect. However, the traditional methods to measure $V_{m}$, with microelectrodes or the whole-cell current-clamp technique, have the drawback that the recording pipette is in contact with the cytoplasm, and dialysis with the pipette solution alters the ionic composition of the interior of the cell. Here we describe a novel technique to determine the $V_{m}$ of an intact cell from the reversal potential of $\mathrm{K}^{+}$currents through
\end{abstract}

a cell-attached patch. Applying the method to interneurons in hippocampal brain slices yielded more negative values for $V_{m}$ than subsequent whole-cell current-clamp measurements from the same cell, presumably reflecting the development of a Donnan potential between cytoplasm and pipette solution in the whole-cell mode. Cell-attached $V_{\mathrm{m}}$ measurements were used to study GABAergic actions in intact CA1 interneurons. In 1- to 3-week-old rats, bath-applied GABA inhibited these cells by stabilizing $V_{m}$ at a level depending on contributions from both $\mathrm{GABA}_{\mathrm{A}}$ and $\mathrm{GABA}_{\mathrm{B}}$ components. In contrast, in 1- to 4-d-old animals, only $\mathrm{GABA}_{A}$ receptors were activated resulting in a depolarizing GABA response.

Key words: hippocampus; interneuron; potassium channels; cell-attached patch-clamp; membrane potential; GABA
GABA is the principal inhibitory neurotransmitter in the mammalian brain. Chloride-permeable channels, with a substantial permeability also for $\mathrm{HCO}_{3}{ }^{-}$(Bormann et al., 1987), open when GABA binds to $\mathrm{GABA}_{\mathrm{A}}$ receptors (Ozawa and Yuzaki, 1984; Gray and Johnston, 1985), whereas binding to $\mathrm{GABA}_{\mathrm{B}}$ receptors leads to $\mathrm{G}$-protein-mediated $\mathrm{K}^{+}$channel activation (Otis et al., 1993). The resulting transmembrane currents either depolarize or hyperpolarize a postsynaptic cell, depending on the equilibrium potentials for these ions and the membrane potential $\left(V_{\mathrm{m}}\right)$ of the cell. Measuring the GABA response reversal potential $\left(E_{\mathrm{GABA}}\right)$ and $V_{\mathrm{m}}$ with classical methods is surprisingly difficult. Penetration with sharp microelectrodes makes a hole in the cell membrane and introduces a significant leak conductance (Spruston and Johnston, 1992), whereas whole-cell patch-clamp electrodes dialyze the cell, imposing the pipette ion concentrations on the recorded cell. Furthermore, whole-cell measurements probably underestimate $V_{\mathrm{m}}$ because an undefined Donnan potential exists between cytoplasm and pipette solution (Marty and Neher, 1995).

These problems may be avoided using a noninvasive approach, based on the reversal potential of $\mathrm{K}^{+}$currents through cellattached patches, to measure $V_{\mathrm{m}}$ (Verheugen et al., 1995). When the $\mathrm{K}^{+}$concentration in the pipette is equal to the intracellular level, the equilibrium potential for $\mathrm{K}^{+}$across the membrane patch is zero. Voltage-gated $\mathrm{K}^{+}$currents $[\mathrm{K}(\mathrm{V})]$, elicited via the patch electrode, will reverse direction when the pipette potential

Received Nov. 30, 1998; revised Jan. 21, 1999; accepted Jan. 25, 1999.

This work was supported by the Human Frontiers Science Organization, the National Institutes of Health (MH54671), and Institut National de la Santé et de la Recherche Médicale. We thank I. Cohen for writing the data analysis program.

Correspondence should be addressed to Dr. Jos A. H. Verheugen, Laboratoire de Neurobiologie Cellulaire et Moleculaire, Institut Pasteur, 25 rue du Dr Roux, 75724 Paris cedex 15, France.

Copyright (C) 1999 Society for Neuroscience $\quad 0270-6474 / 99 / 192546-10 \$ 05.00 / 0$
$\left(-V_{\mathrm{h}}\right)$ equals $V_{\mathrm{m}}$. Repetitive measurements of $\mathrm{K}(\mathrm{V})$ reversal in the cell-attached mode may then be used to follow fluctuations in $V_{\mathrm{m}}$. Furthermore, changes in $\mathrm{K}(\mathrm{V})$ reversal during exposure to GABA and selective agonists of $\mathrm{GABA}_{\mathrm{A}}$ and $\mathrm{GABA}_{\mathrm{B}}$ receptors can provide estimates of respectively $E_{\mathrm{GABA}}, E_{\mathrm{GABA}-\mathrm{A}}$, and $E_{\mathrm{GABA}-\mathrm{B}}$, or at least (in the case other conductances still significantly contribute in setting $V_{\mathrm{m}}$ ) of their polarity with respect to the resting $V_{\mathrm{m}}$.

The relation between $E_{\mathrm{GABA}}$ and $V_{\mathrm{m}}$ of hippocampal interneurons is of particular interest. GABA-mediated membrane currents in hippocampal neurons may be depolarizing in young animals (Mueller et al., 1984; Ben-Ari et al., 1989) and under certain conditions in adult animals (Alger and Nicoll, 1979; Thompson and Gähwiler, 1989; Michelson and Wong, 1991). GABA-mediated depolarizing postsynaptic potentials (Kaila et al., 1997) could function as a source of positive feedback and so synchronize discharge in interneuron networks (Michelson and Wong, 1991). Interneuron synchronization has been implicated in the generation of neonatal hippocampal oscillations (Strata et al., 1997) and of the $40 \mathrm{~Hz}$ gamma rhythm in adult hippocampus and cortex (Whittington et al., 1995). We therefore studied the GABA actions on intact interneurons from rats at different stages of postnatal development using the reversal potential of cellattached $\mathrm{K}(\mathrm{V})$ currents as monitor of $V_{\mathrm{m}}$.

\section{MATERIALS AND METHODS}

Hippocampal slice preparation. Rats aged between 1 and $21 \mathrm{~d}$ were anesthetized by intraperitoneal injection of a ketamine-chloral hydrate solution ( 5 and 18\%, respectively; $1 \mathrm{ml} / 200 \mathrm{gm}$ ). Under deep anesthesia, the vascular system was perfused through the heart with an ice-cold low $\mathrm{Ca}^{2+}$ solution containing (in $\mathrm{mM}$ ): $130 \mathrm{NaCl}, 2.7 \mathrm{KCl}, 20 \mathrm{NaHCO}_{3}, 0.4$ $\mathrm{CaCl}_{2}, 1 \mathrm{MgCl}_{2}, 1.3 \mathrm{NaH}_{2} \mathrm{PO}_{4}$, and 25 glucose, equilibrated with $5 \%$ $\mathrm{CO}_{2}$ and $95 \% \mathrm{O}_{2}$. After perfusion, the brain was removed, and sagittal slices of $200-300 \mu \mathrm{M}$ were cut from the middle third of the hippocampus 

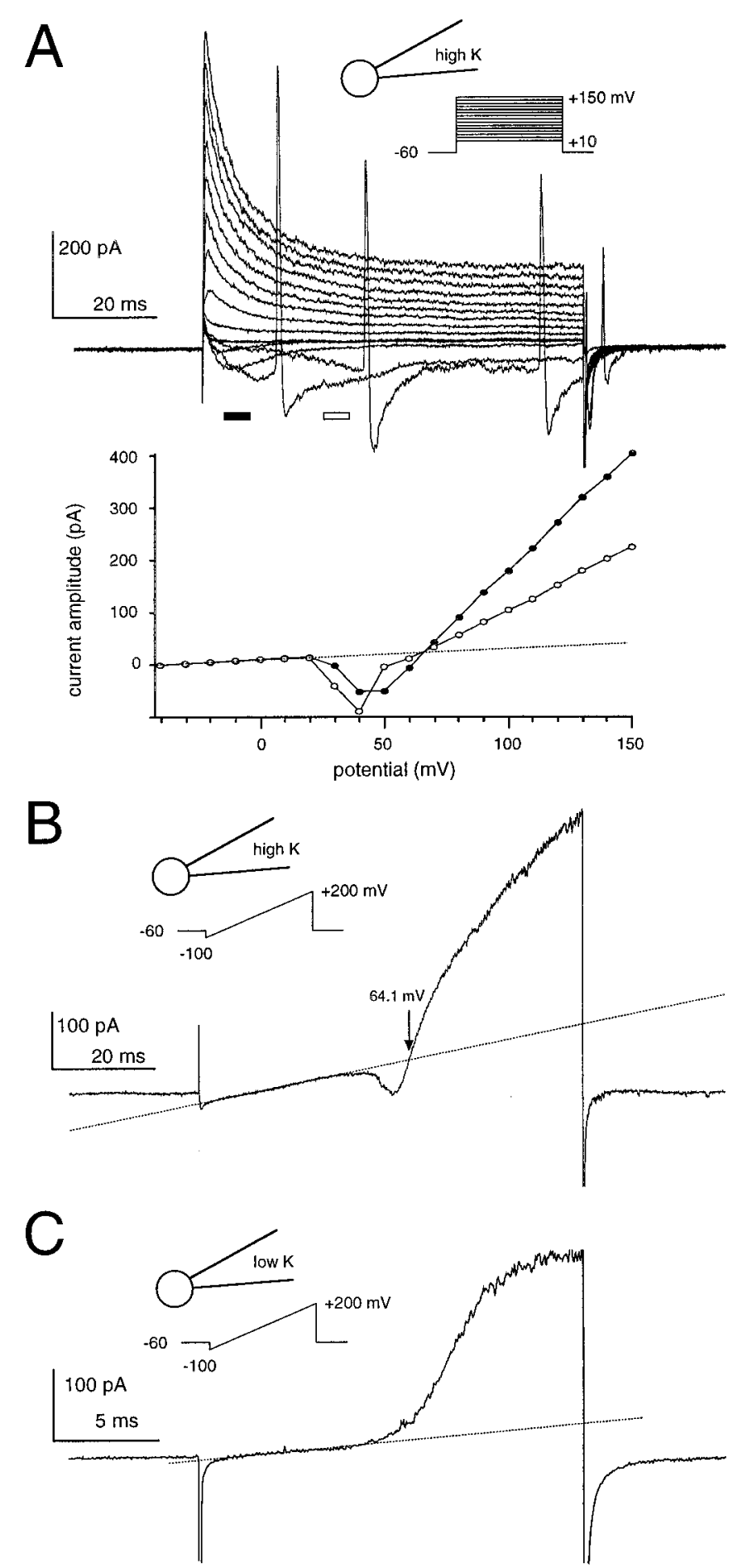

Figure 1. Voltage-gated $\mathrm{K}^{+}$currents measured in cell-attached patches of CA1 interneurons. $A$ shows currents activated by applying depolarizing voltage steps, and $B$ shows the response to a voltage ramp applied to the same cell, with a pipette solution containing $155 \mathrm{~mm} \mathrm{~K}^{+}$. A, The inward $\mathrm{K}^{+}$current caused the generation of action currents in this cell (Lynch and Barry, 1989). At more depolarized potentials the current became outward and consisted of a transient and sustained component. Currentvoltage curves (below), constructed from the average current amplitude at the times indicated by the black and white bars in the top panel, show that the $\mathrm{K}^{+}$current was superimposed on a linear leak (dotted lines) and reversed polarity from inward to outward between +60 and $+70 \mathrm{mV}$. Note that the reversal potential of the voltage-gated current is independent of the relative contributions of the transient and sustained component. $B$, A voltage ramp stimulation gave a similar $I-V$ profile, but no using a vibratome (DTK-1000 microslicer; Dosaka, Kyoto, Japan). Slices were allowed to recover for at least $1 \mathrm{hr}$ in the above solution with $2 \mathrm{~mm}$ $\mathrm{CaCl}_{2}$ ("extracellular solution"). For recordings, slices were placed in a chamber mounted on the stage of a microscope (Nikon Optiphot with a $40 \times, 0.55$ NA objective). They were held in place by a nylon grid and continuously superfused with the oxygenated extracellular solution at room temperature $\left(24-26^{\circ} \mathrm{C}\right)$.

Cell-attached and whole-cell patch-clamp recording. Hippocampal interneurons in stratum radiatum of the CA1 area were visualized using a CCD camera (Hamamatsu C3077) with light filtered to pass visible and infrared. Pipettes (Clark Electromedical Instruments, Pangbourne, UK; GC150 borosilicate glass) with a resistance of 2-6 M 2 were filled with a high $\mathrm{K}^{+}$solution consisting of (in mM): $120 \mathrm{KCl}, 11$ EGTA, $1 \mathrm{CaCl}_{2}, 2$ $\mathrm{MgCl}_{2}, 10$ HEPES, adjusted to pH 7.25 with $35 \mathrm{~mm} \mathrm{KOH} \mathrm{(final} \mathrm{K}{ }^{+}$ concentration $155 \mathrm{~mm}$ ) and to $310 \mathrm{mOsmol}$ with 20 glucose, unless stated otherwise. The junction potential between pipette and extracellular solution ( $<3 \mathrm{mV}$ as measured according to Neher, 1992) was nulled by the voltage-offset of the amplifier (Axopatch 200A) before establishing the seal and was not further corrected. Seal formation was performed under visual control, maintaining positive pressure in the patch electrode when entering into the slice. Stimulation protocols were implemented and data acquired with pClamp6 software (Axon Instruments, Foster City, CA). Currents were low-pass filtered at $5 \mathrm{kHz}$ and digitized at $50-85 \mathrm{kHz}$.

Using the reversal potential of $\mathrm{K}^{+}$currents through cell-attached patches as a monitor of the membrane potential. The method to measure $V_{\mathrm{m}}$ from cell-attached $\mathrm{K}^{+}$currents was adapted from Verheugen et al. (1995) for human T lymphocytes. With a $155 \mathrm{~mm} \mathrm{~K}^{+}$pipette solution, which is the estimated intracellular $\mathrm{K}^{+}$concentration (Hille, 1992), the equilibrium potential for potassium $\left(E_{\mathrm{K}}\right)$ across the patch is $\sim 0 \mathrm{mV}$, and $\mathrm{K}^{+}$currents will reverse when the pipette potential cancels $V_{\mathrm{m}}$ out. Therefore, the holding potential $\left(V_{\mathrm{h}}\right.$, note that for cell-attached recording $V_{\mathrm{h}}=$ $\left.-V_{\text {pipette }}\right)$ at which the $\mathrm{K}^{+}$current reverses direction gives a direct quantitative measure for the cell's membrane potential, $V_{\mathrm{m}}$ (at $\mathrm{K}^{+}$ reversal $V_{\mathrm{m}}+V_{\mathrm{h}}=E_{\mathrm{K}} \approx 0 \mathrm{mV}$ ). With this approach, differences between intracellular and pipette $\mathrm{K}^{+}$concentration would result in errors in the $V_{\mathrm{m}}$ estimate, which will be too negative when $\left[\mathrm{K}^{+}\right]_{\mathrm{i}}<$ $\left[\mathrm{K}^{+}\right]_{\text {pipette }}$. However, with a $\left[\mathrm{K}^{+}\right]_{\text {pipette }}$ of $155 \mathrm{~mm}$ a difference of, for example, $15 \mathrm{~mm}$ would result in an error of $\mathrm{RT} / \mathrm{F} \cdot \ln (155 / 140)<3 \mathrm{mV}$. Depolarizing voltage ramps (from $V_{\mathrm{h}}=-100$ to $+200 \mathrm{mV}$ ) were applied to activate voltage-gated $\mathrm{K}^{+}$channels and to establish the $\mathrm{K}^{+}$current reversal potential. Between stimulations, the patch was held at $-60 \mathrm{mV}$ hyperpolarized with respect to $V_{\mathrm{m}}$ to remove possible voltage-dependent "steady-state" inactivation from the $\mathrm{K}(\mathrm{V})$ channel at the physiological $V_{\mathrm{m}}$. For analysis of currents evoked by ramp stimulation, a correction was made for a leak component by linear extrapolation of the closed level below the threshold for activation of the voltage-gated current (Fig. $1 A, B$, dotted lines $)$. In patches that did not contain $\mathrm{K}(\mathrm{V})$ channels, the leak current was virtually linear in the entire potential range of the voltage ramp (data not shown). Goodness of the linear fit of the leak and determination of the reversal potential from the intersection between the extrapolated fit and $\mathrm{K}^{+}$current were visually confirmed for each individual current trace. Data were analyzed using Axograph 3 (Axon Instruments) or in Labview (National Instruments) using an automated procedure written by Ivan Cohen.

Pharmacology. GABA, muscimol, baclofen, and TTX (all from Sigma, St. Louis, MO) and NBQX and APV (Tocris, Bristol, UK) were made up as $1000 \times$ concentrated stocks and diluted to their final concentrations in the external solution before use. The compounds were applied via bath perfusion. Using a gravity-driven perfusion system, the bath solution completely changed in $\sim 30 \mathrm{sec}$.

\section{RESULTS}

\section{$V_{m}$ measurements from cell-attached $K(V)$ currents}

The membrane potential of interneurons in the stratum radiatum of the CA1 area of hippocampal slices was estimated from the

action currents were generated because of a reduced charge flux. With symmetrical $\mathrm{K}^{+}$, the current reversal at $V_{\mathrm{h}}=+64 \mathrm{mV}$ indicated a membrane potential of $-64 \mathrm{mV}$. $C$, With a low $\mathrm{K}^{+}$pipette solution, in which $135 \mathrm{mM} \mathrm{K}^{+}$was replaced with the impermeant cation $N$-methyl-Dglucamine, the voltage-gated current was outward for all voltages beyond the activation threshold, demonstrating its $\mathrm{K}^{+}$selectivity. 


\section{A cell-attached}
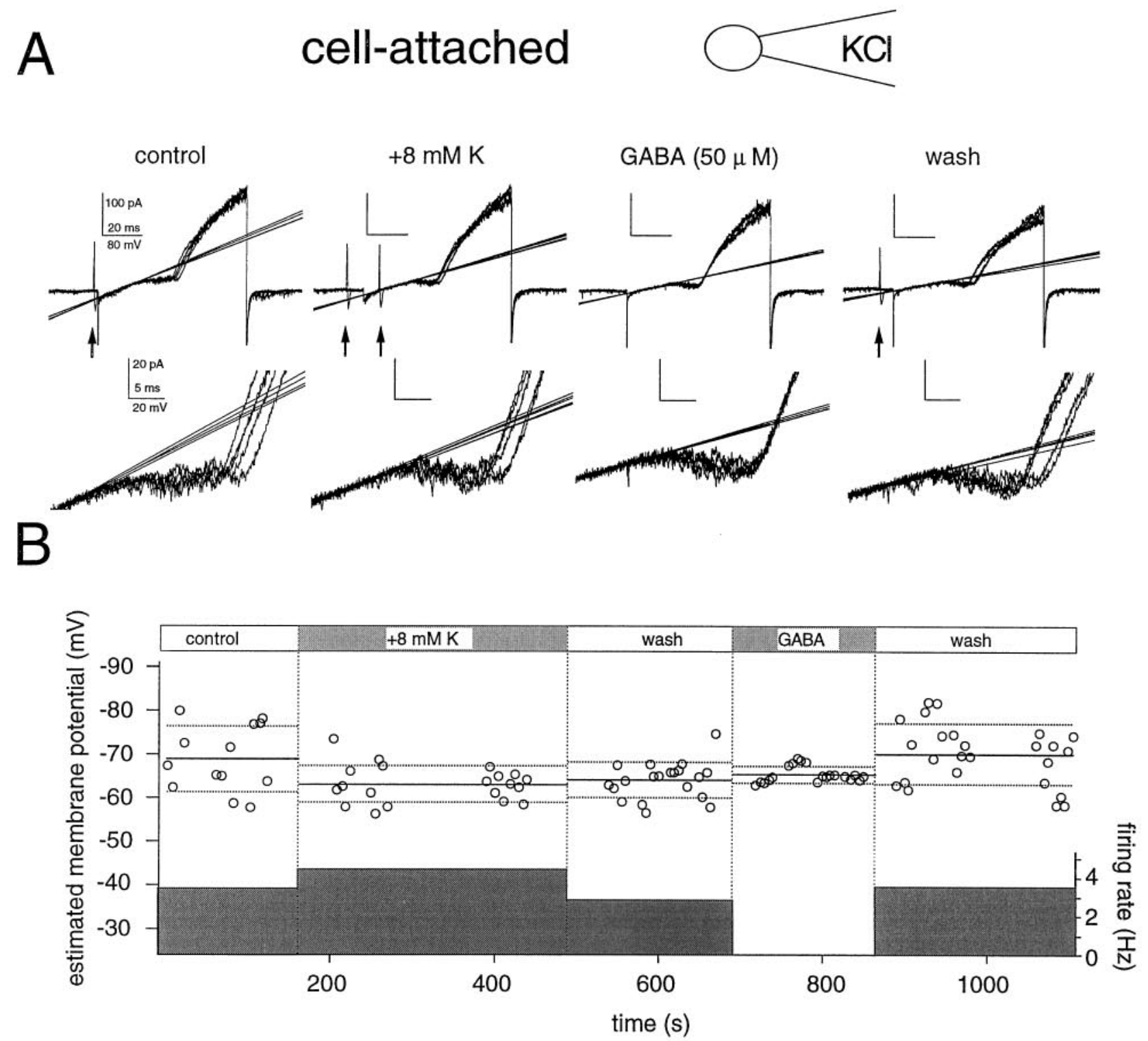

c

whole-cell current-clamp
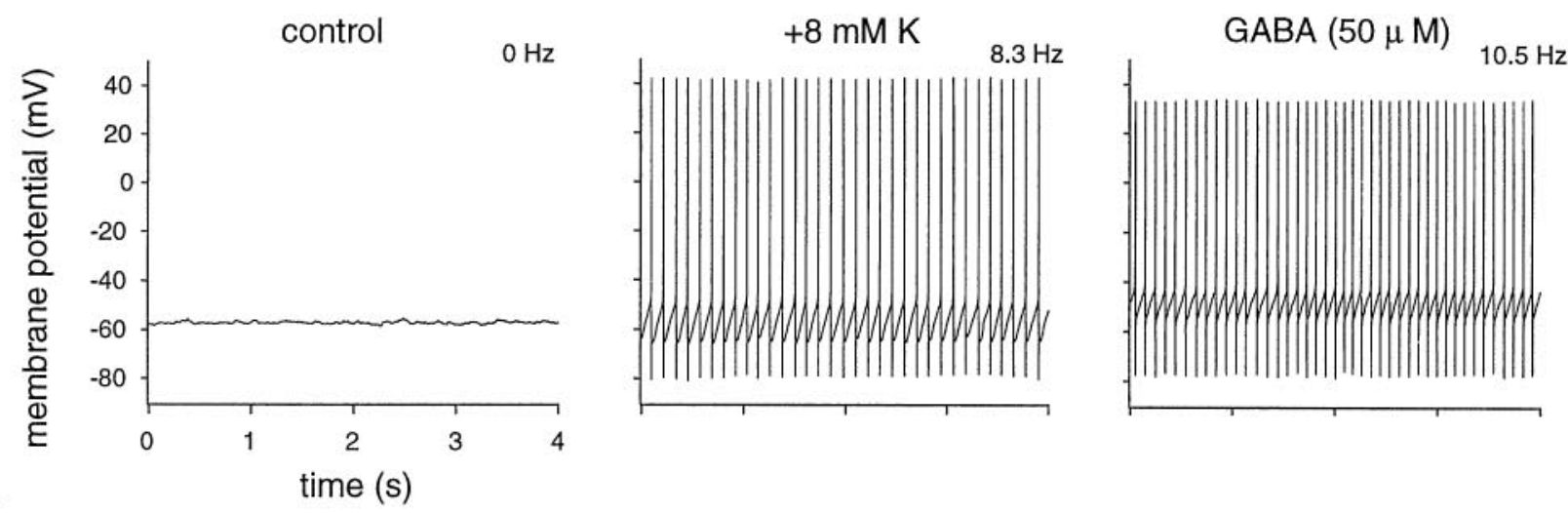

Figure 2. Differences between cell-attached and whole-cell $V_{\mathrm{m}}$ measurements. $A$, Determination of $\mathrm{K}^{+}$current reversal, and hence membrane potential, from a CA1 interneuron after exposure to high external $\left[\mathrm{K}^{+}\right]$and to GABA $(50 \mu \mathrm{M})$. This cell discharged spontaneously, giving rise to action currents visible in the cell-attached record (arrows). For each condition, five consecutive current traces recorded at 2 sec intervals are shown. Bottom panels show the inward $\mathrm{K}(\mathrm{V})$ and its reversal in greater detail. $B$, Plot of $V_{\mathrm{m}}$ determinations (circles; for each condition average $V_{\mathrm{m}}$ and SD (Figure legend continues) 
reversal potential of voltage-gated $\mathrm{K}^{+}$currents activated by command potentials applied via a cell-attached pipette (Fig. 1). This technique permits control of the timing of measurements and is more precise than estimates from changes in amplitude of spontaneous $\mathrm{K}^{+}$channel open events (Zhang and Jackson, 1993; Soltesz and Mody, 1994; Verheugen et al., 1995). Voltage steps applied to somatic patches of interneurons elicited $\mathrm{K}^{+}$currents $\left[I_{\mathrm{K}(\mathrm{V})}\right]$ with a transient (inactivation time constant, $12.9 \pm 4.0$ msec) and a sustained component (Fig. $1 A$ ) corresponding to the $I_{\mathrm{A}}$ and delayed rectifier components of whole-cell $\mathrm{K}^{+}$currents (Zhang and McBain, 1995). With $155 \mathrm{mM} \mathrm{K}^{+}$in the pipette, $\mathrm{K}(\mathrm{V})$ currents were activated between -10 and $+50 \mathrm{mV}$ (relative to $V_{\mathrm{m}}$ ) and were initially inward reaching a maximum amplitude of $32 \pm 35 \mathrm{pA}$. They reversed at potentials between +55 and +90 $\mathrm{mV}$, and outward currents of $279 \pm 204 \mathrm{pA}$ were attained at $+140 \mathrm{mV}$.

Voltage ramp stimulation produced similar $I-V$ relations to those derived from responses to current steps (Fig. 1B). The currents were selective for $\mathrm{K}^{+}$because they were outward over the entire voltage range with pipettes containing low $\mathrm{K}^{+}(20 \mathrm{~mm}$; Fig. 1C). Furthermore, there were no differences in depolarization evoked currents when the pipette solution contained $\mathrm{Cl}^{-}$or gluconate as the main anion ( $p>0.1$; data not shown).

Ramp stimuli were routinely used to determine the $\mathrm{K}(\mathrm{V})$ current reversal potential and hence $V_{\mathrm{m}}$. A correction was made for the linear leak current evident at potentials below the $K(V)$ current threshold (Fig. 1, dotted lines). Short duration (15-20 msec) ramps were preferred because they minimized transmembrane charge flux while still producing close to maximal activation of the $\mathrm{K}(\mathrm{V})$ current (Figs. 2-5). Ramp stimuli could be repeated at frequencies up to $1 \mathrm{~Hz}$ without significant accumulation of use-dependent $\mathrm{K}^{+}$current inactivation. The mean resting $V_{\mathrm{m}}$ of CA1 interneurons, estimated with the cell-attached approach, was $-73 \pm 9 \mathrm{mV}(n=50)$ ranging between -59 and $-93 \mathrm{mV}$.

Large fluctuations in $V_{\mathrm{m}}$, with an amplitude of $21 \pm 6 \mathrm{mV}$, were apparent in a subset of the cells $(n=22$ cells $)$. Action currents were usually visible in the cell-attached records from these neurons (Fig. 2A). The afterhyperpolarizations after the action potentials (APs) (which may be of large amplitudes in CA1 interneurons; Parra et al., 1998) contributed to the fluctuations, which shrank to about half their size during periods without APs (see also Fig. $4 A$ ). Depolarizing the cells by increasing extracellular $\left[\mathrm{K}^{+}\right]$increased the rate of action current generation but reduced fluctuations of $V_{\mathrm{m}}$ because of the smaller amplitude of the AHPs (Fig. 2B). The primary origin of the fluctuations are spontaneously occurring excitatory synaptic events because both the APs and residual fluctuations were largely blocked by applying NBQX/APV to the bath (see below). Bath application of GABA $(50 \mu \mathrm{M})$ also considerably reduced fluctuations in $V_{\mathrm{m}}$ (Fig. $2 B)$. The generation of action currents invariably ceased, and voltage changes caused by spontaneous synaptic events were presumably considerably reduced because of the shunting action of the GABA-dependent increases in $\mathrm{Cl}^{-}$and $\mathrm{K}^{+}$conductances. The residual variability of $V_{\mathrm{m}}$ estimates in the presence of GABA was close to $\pm 2 \mathrm{mV}$, which gives an index of the resolution of the method.

To compare measurements of $V_{\mathrm{m}}$ from $\mathrm{K}^{+}$current reversal in cell-attached records with those determined using the traditional whole-cell current-clamp configuration, the two methods were applied sequentially in experiments on 21 cells. Several differences between the two approaches were apparent (Fig. 2C).

First, values for membrane potential were systematically different. With a high $\mathrm{Cl}^{-}$pipette solution, values for $V_{\mathrm{m}}$ from the cell-attached technique were on average $15 \pm 6 \mathrm{mV}(n=21)$ more hyperpolarized than those measured subsequently from the same cell in current-clamp mode after break-in to the whole-cell configuration (Fig. 2C, left panel). A similar difference $(13 \pm 9$ $\mathrm{mV} ; n=10)$ was observed when the pipette solution contained a low $\mathrm{Cl}^{-}$concentration (14 $\mathrm{mm} \mathrm{Cl}^{-} / 130 \mathrm{~mm}$ gluconate). Second, neuronal discharges were often modified. Action currents were apparent in cell-attached records from the cell shown in Figure 2, but firing ceased once the whole-cell configuration was established. Inversely, cells that were silent in cell-attached records sometimes began to discharge after the transition to the wholecell mode. The changes seemed not to result from dialysis of the cellular cytoplasm with the pipette solution, because they occurred immediately after the membrane was broken and did not depend on the composition of the pipette solution. This point was confirmed by examining the time course of changes in membrane potential and firing after break-in during GABA application, in experiments with pipette solutions containing either a high or a low $\mathrm{Cl}^{-}$concentration. As expected, GABA excited cells recorded in the whole-cell mode with a high $\mathrm{Cl}^{-}$pipette solution (Fig. 2C, right panel), whereas it had an inhibitory action when cells were recorded with a low $\mathrm{Cl}^{-}$solution (data not shown). However, these actions did not occur immediately but had a slow onset that reached a steady-state $0.5-2$ min after break-in as expected if they resulted from intracellular perfusion. These results therefore suggest that the establishment of whole-cell recording alone can modify neuronal excitability, possibly by changing the activation state of voltage-gated channels.

Of note, the observation that intracellular perfusion with a high $\mathrm{Cl}^{-}$solution affects $V_{\mathrm{m}}$ differently under control conditions and after exposure to GABA indicates that in CA1 interneurons $\mathrm{Cl}^{-}$is not the principal ionic species involved in setting the resting level of $V_{\mathrm{m}}$.

\section{Origin of the difference in cell-attached and whole-cell $V_{m}$ estimates}

Two possible explanations were considered to explain the difference in cell-attached and whole-cell estimates for $V_{\mathrm{m}}$. First, it could result from an artifactual shift in $V_{\mathrm{m}}$ induced by the ramp stimulation in cell-attached recordings. Determinations of $V_{\mathrm{m}}$ made using a second independent method based on spontaneous single $\mathrm{K}^{+}$channel openings seem to exclude this explanation.

In some patches, spontaneous openings of non-voltageactivated $\mathrm{K}^{+}$channels were apparent in addition to the $\mathrm{K}(\mathrm{V})$ current gated by membrane depolarization. Figure $3 A$ shows

\section{$\longleftarrow$}

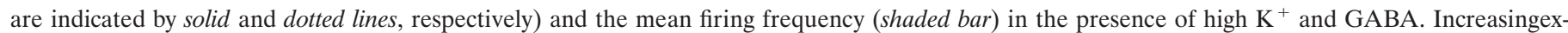

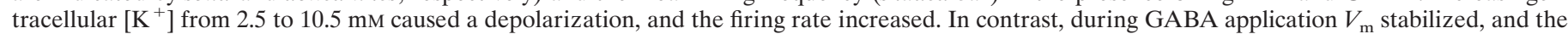

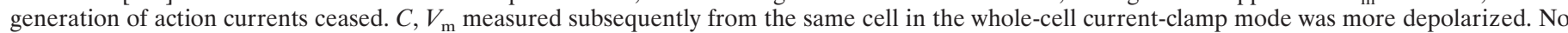

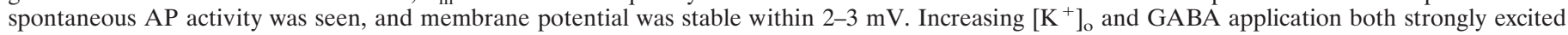
the cell. The pipette solution contained $120 \mathrm{mM} \mathrm{Cl}^{-}$, and the interneuron was recorded from a slice obtained from a $17-\mathrm{d}-\mathrm{old}$ rat. 


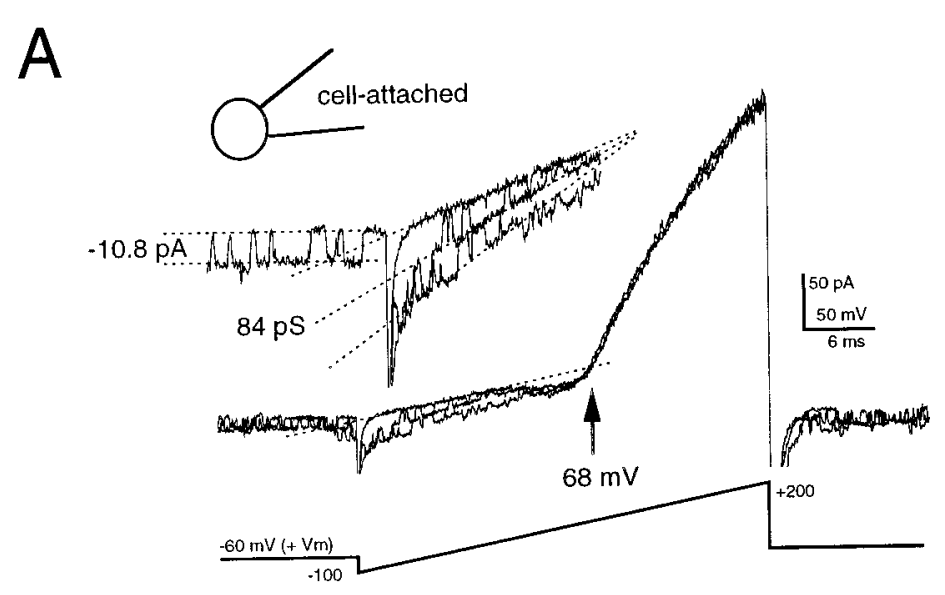

B

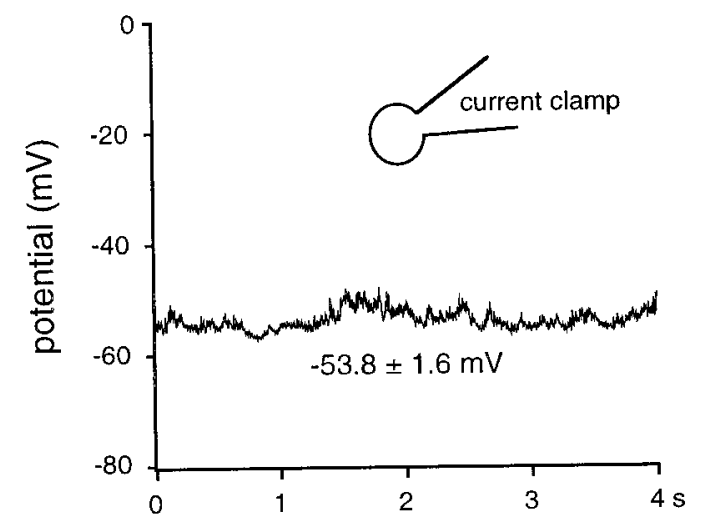

C1

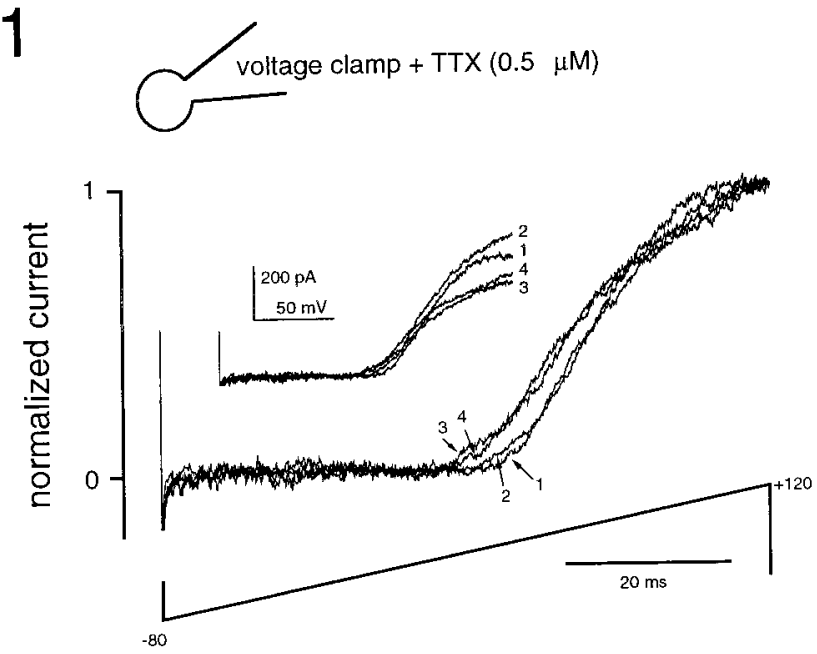

$\mathrm{C} 2$

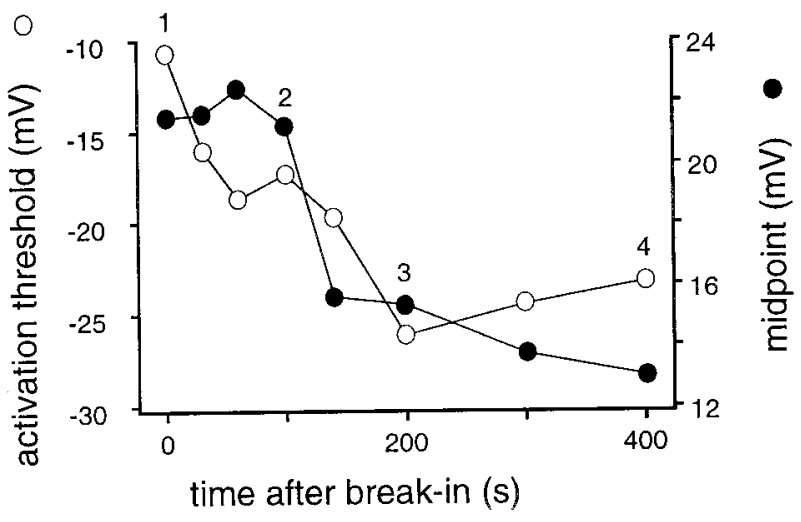

Figure 3. The Donnan potential between cytoplasm and pipette in the whole-cell mode can account for the difference in cell-attached and current-clamp $V_{\mathrm{m}}$ estimates. $A$, Three superimposed cell-attached current traces from a cell with spontaneous single-channel activity (K "ATP"). Two independent estimates for $V_{\mathrm{m}}$ can be obtained from these records. With the single-channel amplitude at $V_{\mathrm{h}}=-60 \mathrm{mV}$ and the single K"ATP" channel conductance calculated from the slope of the open levels during the voltage ramp stimulation, the driving force for $\mathrm{K}^{+}$flux $\left(V_{\mathrm{patch}}-E_{\mathrm{K}}\right.$; with $V_{\mathrm{patch}}=V_{\mathrm{h}}+V_{\mathrm{m}}$ and $E_{\mathrm{K}} \approx 0 \mathrm{mV}$ ) amounts to $10.8 \mathrm{pA} / 84 \mathrm{pS}=128.6 \mathrm{mV}$ at $V_{\mathrm{h}}=-60 \mathrm{mV}$, yielding an estimated $V_{\mathrm{m}}$ of $-68.6 \mathrm{mV}$. The value determined for $V_{\mathrm{m}}$ from reversal of the macroscopic $\mathrm{K}(\mathrm{V})$ current was $-69.2 \mathrm{mV}$. The close agreement between these two values indicates that the ramp stimulation does not significantly affect $V_{\mathrm{m}} . B$, Subsequent whole-cell current-clamp measurement in the same cell gave a value of $-53 \pm 3 \mathrm{mV}$ for $V_{\mathrm{m}}$. $C 1$, Evidence for a change in Donnan junction potential with time after the establishment of whole-cell recordings in the same cell as $A$ and $B$. Whole-cell $\mathrm{K}(\mathrm{V})$ currents activated by ramp stimuli showed a gradual hyperpolarizing shift in voltage dependence. C2, Both the activation threshold (open circles) and the voltage corresponding to the half-maximal current ( filled circles) shifted by approximately $-15 \mathrm{mV}$ during the first $4-8$ min after break-in. Current traces were normalized to compensate for a partial rundown of the $\mathrm{K}(\mathrm{V})$ current $(C 1$, inset $)$. The slice was from a 15-d-old rat.

spontaneous activity of a channel with conductance and inward rectification properties similar to those of an ATP-sensitive $\mathrm{K}^{+}$ channel described in cortical cells (Ohno-Shosaku and Yamamoto, 1992; Sakura et al., 1995). These current records provide two independent means to measure $V_{\mathrm{m}}$. Dividing the single-channel amplitude of K "ATP" by its conductance, calculated from open states during ramp stimuli (see Fig. 3, legend), gives the driving force for current flowing through the channel. The reversal potential was identical for both channels, indicating that they are equally $\mathrm{K}^{+}$selective, and the driving force is therefore the difference between $E_{\mathrm{K}}$ and the patch potential. In the records shown in Figure $3 A$, the single-channel amplitude at $-60 \mathrm{mV}$ for the K"ATP" channel indicates a patch potential of $-128.6 \mathrm{mV}$, and thus a $V_{\mathrm{m}}$ of $-68.6 \mathrm{mV}$ (assuming $E_{\mathrm{K}}=0 \mathrm{mV}$ ). This value was very similar to that determined from the reversal potential of the "macroscopic" voltage-gated $\mathrm{K}^{+}$current $(-69.2 \mathrm{mV})$. This good agreement suggests strongly that neither the inward $\mathrm{K}(\mathrm{V})$ component nor the leak current induced by the voltage ramp significantly affected $V_{\mathrm{m}}$. In eight patches, estimates for $V_{\mathrm{m}}$ using these two distinct approaches always converged within $0-3 \mathrm{mV}$.

A second explanation for the difference between cell-attached and whole-cell measurements of $V_{\mathrm{m}}$ might be the existence of a Donnan potential between the pipette solution and the cytoplasm. Such a potential would lead to an underestimation of the $V_{\mathrm{m}}$ in whole-cell experiments (Barry and Lynch, 1991; Marty and Neher, 1995). The gradual disappearance of a Donnan potential as large anions diff use out of the cell has been monitored as a shift in the apparent voltage dependence of whole-cell currents (Marty and Neher, 1995). In interneurons, depolarizing ramps were applied at regular intervals after break-in to the whole-cell mode to test whether such changes in the voltage dependence of the $\mathrm{K}(\mathrm{V})$ current occurred. In the cell shown in Figure $3, A$ and $B$, the 

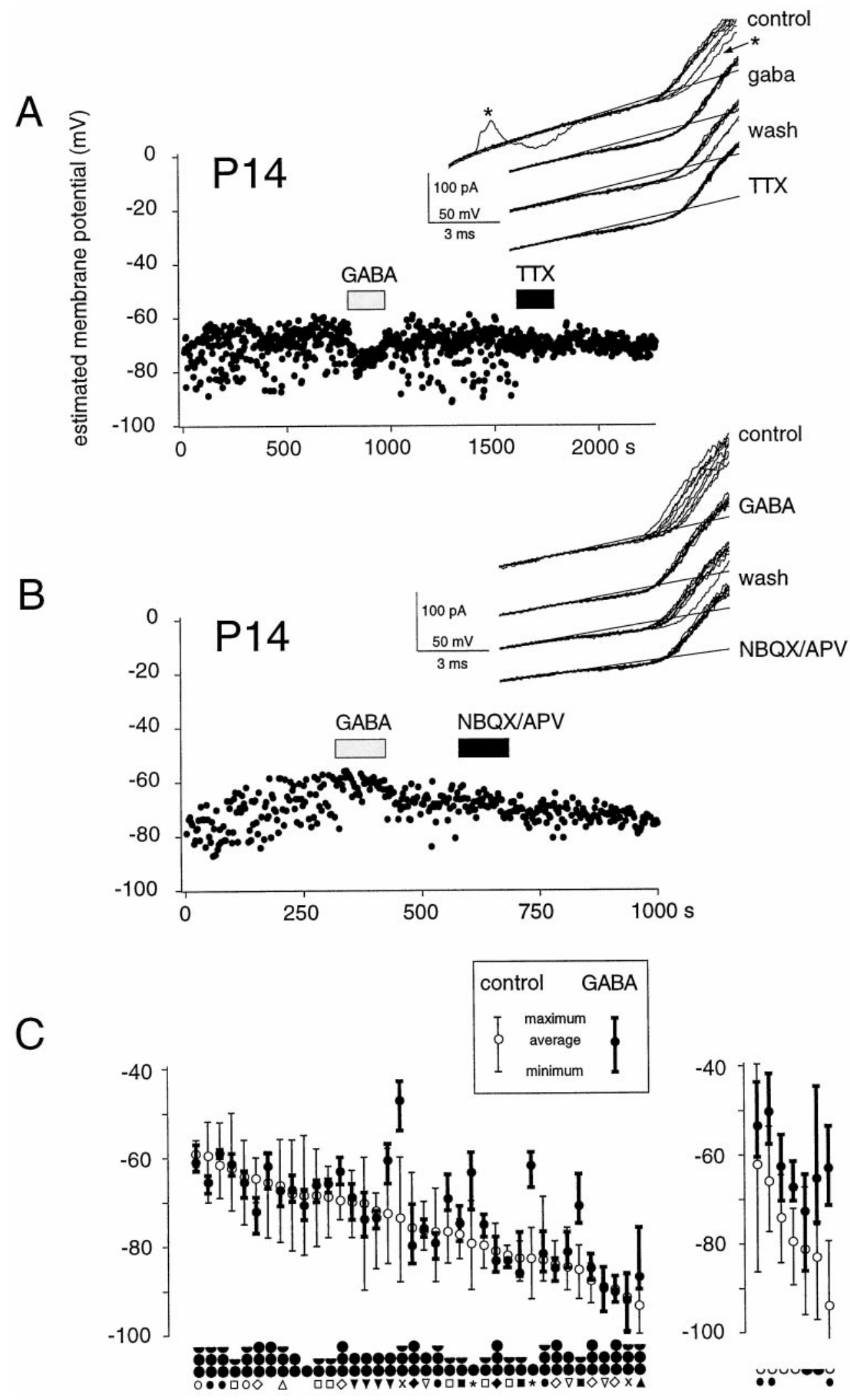

Figure 4. Effects of GABA receptor activation on the $V_{\mathrm{m}}$ of intact CA1 interneurons. $V_{\mathrm{m}}$ of two CA1 interneurons under control conditions and in the presence of bath-applied GABA and TTX $(A)$ and GABA and NBQX/APV $(B)$ monitored from the cell-attached $\mathrm{K}(\mathrm{V})$ current reversal. $V_{\mathrm{m}}$ of both interneurons fluctuated spontaneously, which was associated with AP activity (see current trace in $A$ ). The fluctuations were largely suppressed by TTX $(0.5 \mu \mathrm{M} ; A)$ or by NBQX/APV (20 and $100 \mu \mathrm{M} ; B)$, indicating that they arise from excitatory input to the cell, although the AHPs after action potentials contribute to the hyperpolarizing deflections ( $A$, asterisks). The principal effect of bathapplied GABA in P7-P21 animals is a stabilization of the $V_{\mathrm{m}}$, usually at a level that is not significantly different $(A)$ or slightly depolarized $(B)$ from the average control level. The inset shows for each condition the reversal of $\mathrm{K}(\mathrm{V})$ currents from 10 consecutive cell-attached responses to ramp stimuli applied at $2 \mathrm{sec}$ intervals. $C$, Summary of GABA effects on interneurons from P7-P21 (left) and $\mathrm{P} 1-\mathrm{P} 4$ rats (right). In the older animals, GABA caused $V_{\mathrm{m}}$ to stabilize at a potential close to control level, whereas in young animals it induced a membrane depolarization. Cells are aligned according to the average $V_{\mathrm{m}}$. Minimum and maximum $V_{\mathrm{m}}$ levels are indicated in the presence and absence of GABA. The mean $V_{\mathrm{m}}$ of cells in the two age groups was not significantly different $(p>0.1)$. The black circles under the graph indicate the approximate age of the animal, with each postnatal week corresponding to one circle; an empty half circle indicates 1-to 2-dold rats. Cells originating from the same animal are identified with symbols. difference between values for $V_{\mathrm{m}}$ determined using the cellattached and whole-cell techniques was approximately $-15 \mathrm{mV}$. In the first $20 \mathrm{~min}$ after the onset of whole-cell recording, the $\mathrm{K}(\mathrm{V})$ current-voltage relation shifted by the same order of mag- nitude (Fig. 3C). The mean shift in the $\mathrm{K}(\mathrm{V})$ activation threshold, in the period of 5-20 min after break-in was $-16 \pm 10 \mathrm{mV}(n=$ 5 cells; range, $3-27 \mathrm{mV}$ ), which corresponded to $80 \pm 30 \%$ of the difference in $V_{\mathrm{m}}$ estimates. In the absence of TTX, which was 
A

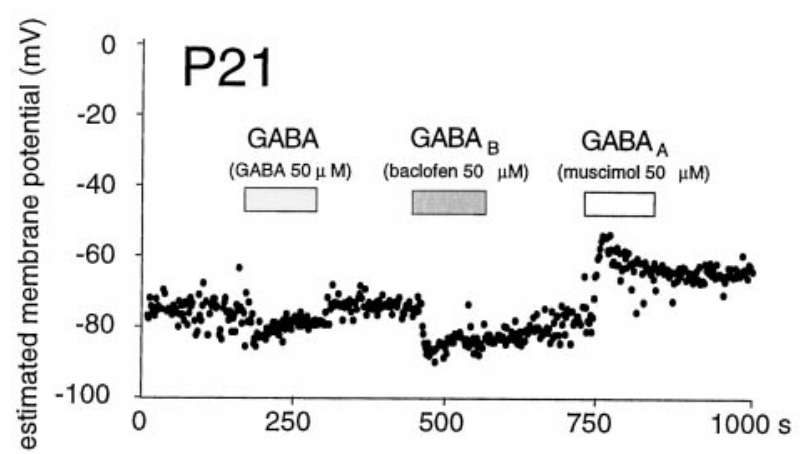

B

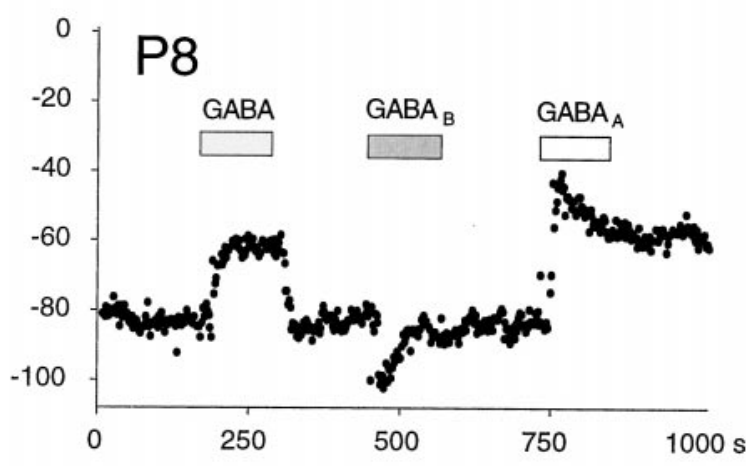

C

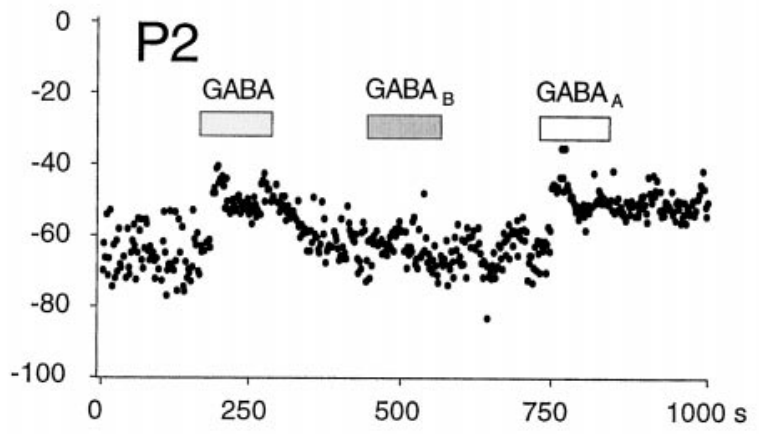

Figure 5. Age dependence of the effects of activating $\mathrm{GABA}_{\mathrm{A}}$ and $\mathrm{GABA}_{\mathrm{B}}$ receptors. Each experiment shows membrane potential responses to application of GABA $(50 \mu \mathrm{M})$, to activation of $\mathrm{GABA}_{\mathrm{B}}$ receptors by baclofen $(50 \mu \mathrm{M})$, and to the activation of $\mathrm{GABA}_{\mathrm{A}}$ receptors by muscimol $(50 \mu \mathrm{M}) . A, B$, In animals older than P7, activation of $\mathrm{GABA}_{\mathrm{A}}$ receptors induced a depolarizing response, whereas $\mathrm{GABA}_{\mathrm{B}}$ receptor activation induced a hyperpolarization. The effects of GABA were a balance depending on combined responses of both receptor subtypes. $C$, In interneurons from young (P1-P4) animals, $\mathrm{GABA}_{\mathrm{B}}$ receptor activation had no effect, and both GABA and muscimol induced depolarizing responses.

used in the above whole-cell experiments to isolate the voltagegated $\mathrm{K}^{+}$currents, similar shifts in voltage dependence of $\mathrm{Na}(\mathrm{V})$ currents after break-in were observed $(n=4$ cells; data not shown).

\section{Effects of GABAergic agonists on $V_{m}$ in intact interneurons}

During experiments to examine Donnan shifts in voltage dependence of $\mathrm{K}^{+}$currents, a partial rundown of the peak current was usually apparent (Fig. $3 C$ ). In contrast, the $\mathrm{K}(\mathrm{V})$ current never ran down in the cell-attached mode. This difference presumably reflects the better conservation of the cytoplasmic environment in cell-attached recordings. Cell-attached measurements of $V_{\mathrm{m}}$ might therefore offer significant advantages in studies on neurotransmitters whose actions depend critically on the cytoplasmic contents. One such neurotransmitter is GABA, which opens $\mathrm{Cl}^{-} / \mathrm{HCO}_{3}{ }^{-}$-permeable channels and activates a G-proteinmediated $\mathrm{K}^{+}$conductance, by activation of $\mathrm{GABA}_{\mathrm{A}^{-}}$and $\mathrm{GABA}_{\mathrm{B}}$-linked ion channels, respectively. We therefore used the cell-attached approach to study the effects of GABA on CA1 interneurons.

Exogenous GABA $(50 \mu \mathrm{M})$ and the selective $\mathrm{GABA}_{\mathrm{A}}$ and $\mathrm{GABA}_{\mathrm{B}}$ agonists muscimol $(50 \mu \mathrm{M})$ and baclofen $(50 \mu \mathrm{M})$ were applied by bath perfusion while monitoring $V_{\mathrm{m}}$ from the reversal of cell-attached $\mathrm{K}^{+}$currents (Fig. 4). Because GABAergic actions on pyramidal cells are reported to change with age (in rabbit: Mueller et al., 1984; in rat: Ben-Ari et al., 1989; Zhang et al., 1991; Chen et al., 1996; Owens et al., 1996), slices were used from animals at various periods after birth. Indeed, there were significant differences in responses to GABA of interneurons from young [postnatal day 1-4 (P1-P4)] and older (P7-P21) animals.

In the older age group, GABA hyperpolarized a small minority of the interneurons $(5 \% ; n=39)$. More cells $(26 \%)$ depolarized in the presence of GABA (Fig. $4 B$ ). However, in the vast majority of the cells $(69 \%)$, no significant change in the average level of $V_{\mathrm{m}}$ occurred (Fig. 4A). These qualitatively different responses to GABA could be observed in interneurons derived from the same animal (Fig. $4 C$ ). Irrespective of the change in average $V_{\mathrm{m}}$, GABA tended to stabilize interneuron membrane potential (Fig. $4 A, B$; see also Fig. 2). This effect was particularly striking in cells with strong $V_{\mathrm{m}}$ fluctuations and spontaneous firing activity, which invariably ceased in the presence of GABA (Figs. 2, 4C).

As described above, these membrane potential fluctuations were usually associated with action current generation and, as expected, were considerably reduced in the presence of a $0.5 \mu \mathrm{M}$ concentration of the $\mathrm{Na}(\mathrm{V})$ channel blocker TTX (Fig. $4 A$ ). It seems probable that action potential generation by these interneurons was largely dependent on excitatory synaptic inputs because exposure to the excitatory amino acid antagonists NBQX $(20 \mu \mathrm{M})$ and APV $(100 \mu \mathrm{M})$ also significantly reduced membrane potential fluctuations (Fig. $4 B$ ). These data suggest therefore that the primary effect of simultaneous strong activation of both $\mathrm{GABA}_{\mathrm{A}}$ and $\mathrm{GABA}_{\mathrm{B}}$ receptors is to stabilize $V_{\mathrm{m}}$ of interneurons from P7-P21 rats, presumably by a shunting action.

In contrast to the relatively small effects on the average level of $V_{\mathrm{m}}$ in older animals, GABA invariably depolarized interneurons from animals aged between 1 and $4 \mathrm{~d}$ (Figs. $4 C, 5 C$ ). In young animals its effect in stabilizing fluctuations in $V_{\mathrm{m}}$ was much less pronounced (Fig. 4C). However, in young animals, as in old, depolarizations induced by GABA rarely caused an excitation. Only in one of seven P1-P4 cells, the depolarization induced by GABA was sufficient to evoke APs.

The contribution of different subtypes of GABA receptors was examined by comparing the effects on $V_{\mathrm{m}}$ of GABA $(50 \mu \mathrm{M})$, muscimol $(50 \mu \mathrm{M})$ to activate $\mathrm{GABA}_{\mathrm{A}}$ receptors, and baclofen (50 $\mu \mathrm{M})$ to activate $\mathrm{GABA}_{\mathrm{B}}$ receptors (Fig. 5). These experiments revealed that responses to GABA depended on the balance between contributions of the $\mathrm{GABA}_{\mathrm{A}}$-activated $\mathrm{Cl}^{-} / \mathrm{HCO}_{3}{ }^{-}$ conductance and the $\mathrm{GABA}_{\mathrm{B}}$-activated $\mathrm{K}^{+}$conductance. Thus, in interneurons from P7-P21 rats, the level at which $V_{\mathrm{m}}$ stabilized in the presence of GABA $(-69 \pm 12 \mathrm{mV}$ from a resting level of $-78 \pm 9 \mathrm{mV} ; n=15)$ was between the hyperpolarized level reached in the presence of baclofen $(-89 \pm 8 \mathrm{mV})$ and the depolarized response to muscimol $(-54 \pm 8 \mathrm{mV}$; Fig. $5 A, B)$. Both 
the $\mathrm{GABA}_{\mathrm{B}}$ - and $\mathrm{GABA}_{\mathrm{A}}$-induced changes in $V_{\mathrm{m}}$ relaxed during prolonged receptor activation, presumably because of redistribution of permeant ions (Kaila, 1994). In contrast, GABA responses remained usually stable during maintained applications.

Whereas GABA and muscimol had different effects on $V_{\mathrm{m}}$ in P7-P21 rats, in interneurons from young animals these two agonists caused similar depolarizations, to $-54 \pm 8 \mathrm{mV}$ and $-55 \pm$ 8 , respectively, from a resting level of $-74 \pm 14 \mathrm{mV}(n=5)$. This difference may be explained by an absence of functional $\mathrm{GABA}_{\mathrm{B}}$ receptors in neurons from $\mathrm{P} 1-\mathrm{P} 4$ animals because baclofen had no effect on $V_{\mathrm{m}}$ (Fig. $5 C$ ). Thus, in these cells, exogenous GABA only increases the $\mathrm{Cl}^{-} / \mathrm{HCO}_{3}{ }^{-}$permeability of the membrane, resulting in a depolarization. Of note, the level of $V_{\mathrm{m}}$ reached in the presence of muscimol was the same for both age groups. Like the depolarizing GABA response in young animals, the depolarization induced by muscimol in both young and older animals was rarely excitatory. Action currents were generated by the muscimol-induced depolarization in one of five P1-P4 cells and in two of 15 P7-P21 cells.

\section{DISCUSSION}

Measurements of neuronal membrane potential and neurotransmitter actions are more difficult than commonly admitted. We have shown that the reversal of voltage-gated $\mathrm{K}^{+}$currents elicited in cell-attached patches can provide a noninvasive way to determine these parameters. This technique has several advantages: (1) it provides a local measure of $V_{\mathrm{m}}$, at the site of the patch; (2) it does not disrupt the cytoplasmic environment; and (3) it avoids Donnan junction potential problems. In this study we validated the technique and used it to examine GABA actions on hippocampal interneurons.

\section{Validation of the technique}

Variations in amplitude of cell-attached currents passing through single potassium channels have previously been used to infer changes in $V_{\mathrm{m}}$ in neurons in response to GABA (Zhang and Jackson, 1993; Soltesz and Mody, 1994) and in T lymphocytes during $\mathrm{Ca}^{2+}$ signaling (Verheugen and Vijverberg, 1995). This technique has the disadvantage that measurements are limited to periods when channels are open. For instance, the $\mathrm{Ca}^{2+}$ activated $\mathrm{K}^{+}$channels used in these studies open only when $\left[\mathrm{Ca}^{2+}\right]_{\mathrm{i}}$ is higher than normal, a state that is usually associated with membrane hyperpolarizations as a consequence of this increase in $\mathrm{K}^{+}$conductance (Verheugen and Korn, 1997). In contrast, the voltage-gated $\mathrm{K}^{+}$channels used to determine the $\mathrm{K}^{+}$ current reversal potential in the present study could be opened by voltage steps applied to the patch at will, independent of intracellular conditions. Furthermore, while changes in single-channel amplitude provide relative estimates of $V_{\mathrm{m}}$, an absolute value of $V_{\mathrm{m}}$ is obtained from the $\mathrm{K}^{+}$current reversal (Verheugen and Vijverberg, 1995).

One potential problem is that the ion current through the $\mathrm{K}(\mathrm{V})$ channels could result in a change of $V_{\mathrm{m}}$ (Fig. $1 A$ ). However, because the patch current is, by definition, zero at the reversal potential, this point should be accurate. The use of fast voltage ramps to determine $\mathrm{K}(\mathrm{V})$ reversal further reduces transmembrane charge fluxes. Similar values for $V_{\mathrm{m}}$ estimates from macroscopic and single-channel currents (Fig. $3 A$ ) provide additional evidence that under the present conditions the cell-attached currents had little influence on $V_{\mathrm{m}}$.

Another potential source of error might be a mismatch between the $\left[\mathrm{K}^{+}\right]$used in our pipette solution and the effective cytoplasmic $\left[\mathrm{K}^{+}\right]$. Deviations from symmetrical $\mathrm{K}^{+}$would result in an $E_{\mathrm{K}}$ across the patch different from $0 \mathrm{mV}$. However, based on the Nernst equation we calculate that an error of for instance 15 $\mathrm{mM}$ in the choice of pipette $\left[\mathrm{K}^{+}\right]$would result in a systematic error of only $3 \mathrm{mV}$ in our determinations of $V_{\mathrm{m}}$.

The $V_{\mathrm{m}}$ values obtained from the cell-attached $\mathrm{K}(\mathrm{V})$ reversal were on average $15 \mathrm{mV}$ more negative than those measured subsequently in whole-cell current-clamp recordings in the same neuron. The existence of a Donnan potential between the cytoplasm and pipette solution immediately after break-in to the whole-cell mode probably accounts for this difference. During the first 5-20 min after the whole-cell configuration was established, the voltage dependence of voltage-gated currents shifted by a similar value (Fig. 3C) most likely corresponding to equilibration between the cytoplasm and the recording pipette and consequent dissipation of the Donnan potential (Marty and Neher, 1995). Therefore, the more negative cell-attached $V_{\mathrm{m}}$ estimates seem likely to be more accurate than the values derived from whole-cell records.

Another advantage of this technique is that the cytoplasmic environment is preserved. In contrast, in the whole-cell technique the pipette solution controls over time the intracellular content, disturbing physiological ion gradients and diluting intracellular factors. The perforated patch technique, which uses antibiotics to render cell membranes permeant to monovalent ions (e.g., nystatin; Horn and Marty, 1988) or selectively to small cations (gramicidin; Ebihara et al., 1995, Kyrozis and Reichling, 1995), thus making electrical contact with the cell interior, avoids these problems to a large extent. Nevertheless, cytoplasmic isolation is not complete, and problems such as an imperfect space-clamp (Müller and Lux, 1993) persist. In contrast, $V_{\mathrm{m}}$ measurements based on cell-attached $\mathrm{K}^{+}$current reversal concerns the local potential at the site of the patch, whereas $V_{\mathrm{m}}$ of the attached cell is not clamped and able to show unrestrained physiological fluctuations. The point nature of this type of measurement may eventually prove useful to study possible regional variations in $V_{\mathrm{m}}$ over the neuronal membrane.

\section{Measurements of GABA actions on hippocampal interneurons}

Actions of the neurotransmitter GABA depend crucially on the intracellular activities of $\mathrm{Cl}^{-}, \mathrm{HCO}_{3}{ }^{-}$, and $\mathrm{K}^{+}$ions. For example, concentration shifts of these ions are thought to occur during prolonged GABAergic stimulation (see below). Because it does not perturb the cytoplasm, a cell-attached approach to determine $V_{\mathrm{m}}$ is particularly well suited to explore GABA actions. Although the time resolution of this technique (limited to $\sim 1 \mathrm{~Hz}$ ) did not permit individual synaptic events to be resolved, the effects on $V_{\mathrm{m}}$ of exogenous applied GABA or selective agonists for $\mathrm{GABA}_{\mathrm{A}}$ and $\mathrm{GABA}_{\mathrm{B}}$ receptors are easily detected.

We found that bath-applied GABA stabilized the $V_{\mathrm{m}}$ of interneurons at a level similar to its control value in slices from animals aged 1-3 weeks. Dissection of this response using selective agonists suggested that the membrane stabilization represented a balance between a hyperpolarizing action via $\mathrm{GABA}_{\mathrm{B}}$ receptors and a depolarization mediated by $\mathrm{GABA}_{\mathrm{A}}$ receptor activation. In contrast, in animals aged $1-4 \mathrm{~d}$, the $\mathrm{GABA}_{\mathrm{B}}$ receptor agonist baclofen had no effect, as observed also in CA3 pyramidal cells at a similar developmental stage (Strata and Cherubini, 1994; Gaiarsa et al., 1995), and the depolarizing $\mathrm{GABA}_{\mathrm{A}}$-mediated response predominated. Even in P1-P4 animals the $\mathrm{GABA}_{\mathrm{A}^{-}}$ dependent depolarization rarely induced cell firing, as judged by 
an absence of action currents from cell-attached records. The stabilization of $V_{\mathrm{m}}$ induced by GABA in neurons from older animals, and to a lesser extent also young animals, presumably reflects the shunting of the cell membrane by the GABAactivated conductances (Staley and Mody, 1992; Z hang and Jackson, 1993).

The origin of depolarizing responses to $\mathrm{GABA}_{\mathrm{A}}$ receptor activation remains to be completely understood. In this study, muscimol depolarized CA1 interneurons to similar membrane potentials, close to $-55 \mathrm{mV}$, in animals from all ages that we examined (Fig. 5). There are numerous reports of biphasic $\mathrm{GABA}_{\mathrm{A}}$ responses generated in pyramidal cells, either by repetitive synaptic stimulation or by applying exogenous GABA. These responses consist of a short initial hyperpolarization, followed by a prolonged depolarization (Alger and Nicoll, 1979; Staley et al., 1995; Kaila et al., 1997). It seems probable that the time resolution of our method was not sufficient to capture the initial hyperpolarization and that we largely recorded the depolarizing component of the response. This component may result from an activity-dependent collapse of the $\mathrm{Cl}^{-}$gradient after which the $\mathrm{HCO}_{3}{ }^{-}$current through the $\mathrm{GABA}_{\mathrm{A}}$ channel becomes dominant (Staley et al., 1995) analogous to the mechanism in crayfish muscle (Kaila et al., 1989). An additional depolarization may result from an increase in extracellular $\left[\mathrm{K}^{+}\right]$(Barolet and Morris, 1991) because of the activity in other interneurons (Kaila et al., 1997), although our results showing that GABA did not enhance cell firing might argue against this.

The observation that muscimol depolarizes $V_{\mathrm{m}}$ of CA1 interneurons in young and old animals to exactly the same level could suggest that the $\mathrm{Cl}^{-}$reversal potential is the same for both age groups, in contrast to what has been suggested for hippocampal pyramidal cells (Mueller et al., 1984; Ben-Ari et al., 1989), and that in interneurons age-related changes in GABAergic action arise primarily from a change in functional receptor repertoire. However, the possible ionic shifts associated with the prolonged GABAergic stimulation in the present experiments precludes a reliable estimation of resting levels of intracellular ions, and other experiments in which ion shifts are somehow controlled are needed to specifically address the question of developmental changes in $\mathrm{Cl}^{-}$homeostasis.

In this study we assessed the effects of GABA receptor activation on $V_{\mathrm{m}}$ from the reversal of somatic $\mathrm{K}^{+}$fluxes. This approach yields a point potential at the somatic patch, which may differ from that at other membrane surface sites (Spruston and Johnston, 1992). It might be especially interesting to use this technique to look for differences between somatic and dendritic responses to GABA receptor activation (Misgeld et al., 1986; Staley et al., 1995; Kaila et al., 1997).

\section{REFERENCES}

Alger BE, Nicoll RA (1979) GABA-mediated biphasic inhibitory responses in hippocampus. Nature 281:315-317.

Barolet AW, Morris ME (1991) Changes in extracellular $\mathrm{K}^{+}$evoked by GABA, THIP, and baclofen in the guinea-pig hippocampal slice. Exp Brain Res 84:591-598.

Barry PH, Lynch JW (1991) Liquid junction potentials and small cell effects in patch-clamp analysis. J Membr Biol 121:101-117.

Ben-Ari Y, Cherubini E, Corradetti R, Gaiarsa J-L (1989) Giant synaptic potentials in immature rat CA3 hippocampal neurones. J Physiol (Lond) 416:303-325.

Bormann J, Hamill OP, Sakmann B (1987) Mechanism of anion permeation through channels gated by glycine and $\gamma$-aminobutyric acid in mouse cultured spinal neurones. J Physiol (Lond) 385:243-286.

Chen G, Trombley PQ, van den Pol AN (1996) Excitatory actions of
GABA in developing rat hypothalamic neurones. J Physiol (Lond) 494:451-464.

Ebihara S, Shirato K, Harata N, Akaike N (1995) Gramicidin-perforated patch recording: GABA response in mammalian neurones with intact intracellular chloride. J Physiol (Lond) 484:77-86.

Gaiarsa J-L, Tseeb V, Ben-Ari Y (1995) Postnatal development of preand postsynaptic $\mathrm{GABA}_{\mathrm{B}}$-mediated inhibitions in the CA3 hippocampal region of the rat. J Neurophysiol 73:246-255.

Gray R, Johnston D (1985) Rectification of single GABA-gated chloride channels in adult hippocampal neurons. J Neurophysiol 54:134-142.

Hille B (1992) Ionic channels of excitable membranes, Ed 2. Sunderland, MA: Sinauer.

Horn R, Marty A (1988) Muscarinic activation of ionic currents measured with a new whole-cell recording method. J Gen Physiol 92:145-159.

Kaila K, Pasternack M, Saarikoski J, Voipio J (1989) Influence of GABA-gated bicarbonate conductance on membrane potential, current, and intracellular chloride in crayfish muscle fibers. J Physiol (Lond) 416:161-181.

Kaila K (1994) Ionic basis of $\mathrm{GABA}_{\mathrm{A}}$ receptor channel function in the nervous system. Prog Neurobiol 42:489-537.

Kaila K, Lamsa K, Smirnov S, Taira T, Voipio J (1997) Long-lasting GABA-mediated depolarization evoked by high-frequency stimulation in pyramidal neurons of rat hippocampal slice is attributable to a network-driven, bicarbonate-dependent $\mathrm{K}^{+}$transient. J Neurosci 17:7662-7672.

Kyrozis A, Reichling DB (1995) Perforated-patch recording with gramicidin avoids artifactual changes in intracellular chloride concentration. J Neurosci Methods 57:27-35.

Lynch JW, Barry PH (1989) Action potentials initiated by single channels opening in a small neuron (rat olfactory receptor). Biophys J 55:755-768.

Marty A, Neher E (1995) Tight-seal whole-cell recording. In: Single channel recording (Sakmann B, Neher E, eds), pp 31-52. New York: Plenum.

Michelson HB, Wong RKS (1991) Excitatory synaptic responses mediated by $\mathrm{GABA}_{\mathrm{A}}$ receptors in the hippocampus. Science 253:1420-1423.

Misgeld U, Deisz RA, Dodt HU, Lux HD (1986) The role of chloride transport in postsynaptic inhibition of hippocampal neurons. Science 232:1413-1415.

Mueller AL, Taube JS, Schwartzkroin PA (1984) Development of hyperpolarizing inhibitory postsynaptic potentials and hyperpolarizing response to $\gamma$-aminobutyric acid in rabbit hippocampus studied in vitro. J Neurosci 4:860-867.

Müller W, Lux HD (1993) Analysis of voltage-dependent membrane currents in spatially extended neurons from point-clamp data. J Neurophysiol 69:241-247.

Neher E (1992) Correction for liquid junction potentials in patch-clamp experiments. In: Ion channels; Methods in enzymology, Vol 207, pp 123-131. New York: Academic.

Ohno-Shosaku T, Yamamoto C (1992) Identification of an ATPsensitive $\mathrm{K}^{+}$channel in rat cultured cortical neurons. Pflügers Arch 422:260-266.

Otis TS, De Koninck Y, Mody I (1993) Characterization of synaptically elicited $\mathrm{GABA}_{\mathrm{B}}$ responses using patch-clamp recordings in rat hippocampal slices. J Physiol (Lond) 463:391-407.

Owens DF, Boyce LH, Davis MB, Kriegstein AR (1996) Excitatory GABA responses in embryonic and neonatal cortical slices demonstrated by gramicidin perforated-patch recordings and calcium imaging. J Neurosci 16:6414-6423.

Ozawa S, Yuzaki M (1984) Patch-clamp studies of chloride channels activated by gamma-aminobutyric acid in cultured hippocampal neurones of the rat. Neurosci Res 1:275-293.

Parra P, Gulyas AI, Miles R (1998) How many subsets of inhibitory cells in the hippocampus? Neuron 20:983-993.

Sakura H, Ammala C, Smith PA, Gribble FM, Ashcroft FM (1995) Cloning and functional expression of the cDNA encoding a novel ATP-sensitive potassium channel subunit expressed in pancreatic betacells, brain, heart and skeletal muscle. FEBS lett 377:338-344.

Soltesz I, Mody I (1994) Patch-clamp recordings reveal powerful GABAergic inhibition in dentate hilar neurons. J Neurosci 14:2365-2376.

Spruston N, Johnston D (1992) Perforated patch-clamp analysis of the passive membrane properties of three classes of hippocampal neurons. J Neurophysiol 67:508-529. 
Staley KJ, Mody I (1992) Shunting of excitatory input to dentate gyrus granule cells by a depolarizing $\mathrm{GABA}_{\mathrm{A}}$ receptor-mediated postsynaptic conductance. J Neurophysiol 68:197-212.

Staley KJ, Soldo BL, Proctor WR (1995) Ionic mechanisms of neuronal

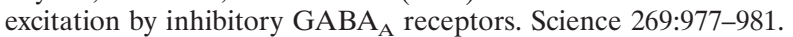

Strata F, Cherubini E (1994) Transient expression of a novel type of GABA response in rat CA3 hippocampal neurones during development. J Physiol (Lond) 480:493-503.

Strata F, Atzori M, Molnar M, Ugolini G, Tempia F, Cherubini E (1997) A pacemaker current in dye-coupled hilar interneurons contributes to the generation of giant GABAergic potentials in developing hippocampus. J Neurosci 17:1435-1446.

Thompson SM, Gähwiler BH (1989) Activity-dependent disinhibition, I: repetitive stimulation reduces IPSP driving force and conductance in the hippocampus in vitro. J Neurophysiol 61:501-511.

Verheugen JAH, Vijverberg HPM (1995) Intracellular $\mathrm{Ca}^{2+}$ oscillations and membrane potential fluctuations in intact human $\mathrm{T}$ lymphocytes: role of $\mathrm{K}^{+}$channels in $\mathrm{Ca}^{2+}$ signaling. Cell Calcium 17:287-300.
Verheugen JAH, Vijverberg HPM, Oortgiesen M, Cahalan MD (1995) Voltage-gated and $\mathrm{Ca}^{2+}$-activated $\mathrm{K}^{+}$channels in intact human $\mathrm{T}$ lymphocytes: non-invasive measurements of membrane currents, membrane potential, and intracellular calcium. J Gen Physiol 105:765-794.

Verheugen JAH, Korn H (1997) A charybdotoxin-insensitive potassium conductance in human T lymphocytes: T cell membrane potential is set by distinct $\mathrm{K}^{+}$channels. J Physiol (Lond) 503:317-331.

Whittington MA, Traub RD, Jefferys JGR (1995) Synchronized oscillations in interneuron networks driven by metabotropic glutamate receptor activation. Nature 373:612-615.

Zhang L, McBain CJ (1995) Voltage-gated potassium currents in stratum oriens-alveus inhibitory neurones of the rat CA1 hippocampus. J Physiol (Lond) 488:647-660.

Zhang L, Spigelman I, Carlen PL (1991) Development of GABAmediated, chloride-dependent inhibition in CA1 pyramidal neurones of immature rat hippocampal slices. J Physiol (Lond) 444:25-49.

Zhang SJ, Jackson MB (1993) GABA-activated chloride channels in secretory nerve endings. Science 259:531-534. 